\title{
Studies on Agglutination-Inhibitory Substances on Germinated Spores of Ceratocystis fimbriata, Black Rot Fungus
}

\author{
Kazuhito KawaKita and Mineo KoJIMA \\ Institute for Biochemical Regulation, Faculty of Agriculture, \\ Nagoya University, Chikusa, Nagoya 464, Japan
}

Received June 11, 1984

\begin{abstract}
Ungerminated spores of the sweet potato strain of Ceratocystis fimbriata are highly sensitive to spore-agglutinating factor (SA factor) from sweet potato roots and are agglutinated by the factor at low concentrations. However, they become less sensitive to the factor when they germinate. The substances (SAI substances) that inhibited spore agglutination by SA factor were released by sonication from the surface of germinated spores of the sweet potato strain and isolated. The substances seemed to re-bind efficiently onto the surface of the sonicated spores at $\mathrm{pH} 6.5$ in the presence of $\mathrm{Ca}^{2+}(10 \mathrm{mM})$ and this made them less sensitive to SA factor. The substances were assumed to be proteins from the inactivation by heat and trypsin treatments. The substances diminished, to a similar degree, the sensitivity to SA factor of germinated spores of all seven strains of $C$. fimbriata; the sweet potato, coffee, prune, cacao, oak, taro, and almond strains. The substances stimulated the growth of sweet potato, coffee, cacao, and taro strains in liquid media, while the growth of prune, oak, and almond strains were inhibited by the substances. These results are discussed in relation to differential agglutination of germinated spores of various strains by SA factor and to host-parasite specificity.
\end{abstract}

In recent years, suggestive evidence that lectins or agglutinating factors are involved in the determination of plant host-parasite specificity have been obtained on some hostparasite systems. ${ }^{1 \sim 9)}$ Bohlool and Schmidt ${ }^{2)}$ showed that soybean seed lectins bind to symbiotic strains of Rhizobium japonicum, but did not bind to any of the 23 nonsymbiotic strains. Dazzo et al. ${ }^{3 \sim 5)}$ presented strong evidence that a protein agglutinin, trifoliin in white clover, determined the specificity in symbiosis of Rhizobium trifolii. Goodman et al. ${ }^{6,7)}$ indicated that an avirulent strain of Erwinia amylovora was agglutinated and immobilized in the xylem vessels of apple shoots.

In our previous papers, ${ }^{10 \sim 12)}$ we also suggested the involvement of spore-agglutinating factor (SA factor) in the determination of hostparasite specificity between various plants and various strains of Ceratocystis fimbriata, black rot fungus.

The ungerminated spores of various strains of $C$. fimbriata were agglutinated similarly by SA factor from sweet potato roots, although there was a small difference among strains. On germination, spores of the sweet potato strain, which is compatible with sweet potato, became highly insensitive to the factor. On the other hand, all but one of the other incompatible strains, the coffee, prune, cacao, oak, and taro strains, but not the almond strain, remained sensitive to the factor after germination. ${ }^{12)} \mathrm{We}$ suggested in our preceeding paper, ${ }^{13)}$ that insensitiveness of germinated spores of the sweet potato strain to SA factor was attributable to the agglutination-inhibitory substance(s) (SAI substances) which appeared on their surface upon germination.

In this paper, we isolated and characterized SAI substances from germinated spores of the sweet potato strain. In addition, we studied the effects of the substances on spore agglutination and growth of various strains.

\section{MATERIALS AND METHODS}

Plant materials. Sweet potato roots (Ipomoea batatas Lam, cv. Norin 1) were harvested in October and stored at 
$13^{\circ} \mathrm{C}$ until used. Parenchymal tissues were used for experiments.

Preparation of the germinated spores of $C$. fimbriata. The germinated spores of sweet potato, coffee, prune, cacao, oak, taro, and almond strains of $C$. fimbriata were prepared by the method reported previously. ${ }^{14)}$ Spores used in experiment of Fig. 1 were prepared aseptically. On sweet potato, only the sweet potato strain is pathogenic, while all other strains are non-pathogenic.

Assay of spore-agglutinating activity. Spore-agglutinating activity was assayed by our earlier method. ${ }^{12)}$ The degree of agglutination is presented as a relative agglutination value on an arbitrary scale where +1 represents the lowest amount of agglutination detectable by the unaided eye. Minus in the tables denotes no agglutination.

Preparation of $S A$ factor. SA factor was isolated from sweet potato roots according to the procedure of our previous paper. ${ }^{12)}$ The amount of SA factor is expressed by the amount of galacturonic acid it contained, as determined by the carbazole ${ }^{15)}$ or $m$-hydroxydipheny ${ }^{16 \text { ) }}$ reactions.

Sonication of germinated spores. The germinated spores of the sweet potato strain were sonicated at a strength of $40 \mathrm{~W}$ for $5 \mathrm{~min}$ in a Kubota Insonator $200 \mathrm{M}$ (Kubota Co, Tokyo). The sonicated spores were washed five times with water by centrifugation.

Assay of agglutination-inhibitory activity. The germinated spores of the sweet potato strain which had been sonicated as described above were dispersed with a Teflon homogenizer. The spores $\left(1.2 \times 10^{7}\right.$ spores $)$ were incubated in $0.9 \mathrm{ml}$ of $10 \mathrm{~mm}$ MES-NaOH buffer, $\mathrm{pH} 6.5$, containing a fixed amount or varied amounts of SAI substances to be assayed and $5 \mathrm{mM} \mathrm{CaCl}_{2}$ in a $15 \mathrm{ml}$ vial on a shaker at 100 strokes $/ \mathrm{min}$ at $25^{\circ} \mathrm{C}$. After incubation for $20 \mathrm{~min}$, the second incubation was started by addition of varied amounts of SA factor in $50 \mu \mathrm{l}$ and $5 \mu \mathrm{mol}$ of $\mathrm{CaCl}_{2}$ in $50 \mu \mathrm{l}$, both of which had been adjusted to $\mathrm{pH} \mathrm{6.5}$. The incubation was continued for $20 \mathrm{~min}$ and the mixture was examined for agglutination by the unaided eye. One unit of spore-agglutination inhibitory activity is defined as the activity inhibiting the agglutination to the lowest detectable level in the assay mixture containing $0.25 \mu \mathrm{g}$ of galacturonic acid equivalent of SA factor. Assays were carried out by serial dilutions of samples. Sample titers were calculated from the highest dilution of samples showing 1 unit of inhibitory activity.

Preparation of SAI substances. The germinated spore suspension $\left(1.2 \times 10^{7}\right.$ spores $\left./ \mathrm{ml}\right)$ of the sweet potato strain was sonicated at a strength of $40 \mathrm{~W}$ for $5 \mathrm{~min}$ in the Kubota Insonator $200 \mathrm{M}$. The sonicated suspension was centrifuged at $2,300 \times g$ for $5 \mathrm{~min}$. The resulting supernatant was used as SAI substances preparation. The SAI substances preparation used in the experiment shown in Fig. 1 was freed from lower molecular weight compounds by passing through a Sephadex G- 25 column. The amount of the SAI substances is denoted by the protein contents determined by the method of Lowry et al. ${ }^{17)}$

Trypsin treatment of SAI substances. SAI substances $(400 \mu \mathrm{g}$ protein) were incubated with $6 \mu \mathrm{g}$ of trypsin (Sigma, diphenyl carbamyl chloride treated) in $0.5 \mathrm{ml}$ of $10 \mathrm{~mm}$ Tris- $\mathrm{HCl}$ buffer, $\mathrm{pH} 8.0$, containing $10 \mathrm{~mm} \mathrm{CaCl}_{2}$ at $25^{\circ} \mathrm{C}$. After incubation for $6 \mathrm{hr}, 14 \mu \mathrm{g}$ of trypsin inhibitor (Boehringer) in $0.02 \mathrm{ml}$ of water was added to the mixture and incubated for $30 \mathrm{~min}$.

Effects of SAI substances on growth of C. fimbriata in liquid media. The ungerminated spores $\left(9.0 \times 10^{6}\right.$ spores $)$ of various strains were incubated in $1 \mathrm{ml}$ of mixture containing $10 \mu \mathrm{mol}$ MES-NaOH buffer, $\mathrm{pH} 6.5,500 \mu \mathrm{g}$ protein of SAI substances, $10 \mu \mathrm{mol}$ of $\mathrm{CaCl}_{2}$ and $50 \mu \mathrm{l}$ of sweet potato water-extract ( $1 \mathrm{ml}$ of water $/ 1 \mathrm{~g}$ of tissue) as nutrients. After incubation for $18 \mathrm{hr}$ at $25^{\circ} \mathrm{C}$ on a shaker at 100 strokes/min, the growth was assayed by the packed volume in a hematocrit tube after centrifugation at $2,300 \times g$ for $5 \mathrm{~min}$. Growth rate was denoted as the percentage of that of the control sample without addition of SAI substances.

In this experiment, all operations were carried out aseptically; MES-NaOH buffer and SAI substances were sterilized by filtration through Minisart $\mathrm{N}$ (Sartorius $\mathrm{GmbH}$ ) and others were sterilized by autoclaving.

\section{RESULTS}

\section{Release of SAI substances from germinated spores of sweet potato strain}

As shown in Table I, germinated spores of the sweet potato strain were highly insensitive to SA factor from sweet potato roots and were not agglutinated by SA factor in the concentrations tested. On the other hand, they became sensitive to SA factor and were agglutinated by the lowest concentration $(25 \mathrm{ng}$ galacturonic acid equivalent $/ \mathrm{ml}$ ) of SA factor, when they were sonicated and washed. The sonicated spores, however, returned to the insensitive state to SA factor when they were pre-incubated with the substances released by sonication.

\section{Characterization of SAI substances}

The SAI substances prepared lost its activity 
Table I. Effects of Sonication and Pre-treatment with Sonication-released Substances on Agglutination of Germinated Spores of Sweet Potato Strain

The germinated spores of sweet potato strain were sonicated as mentioned under MATERIALS AND MEthods. The sonicated spores $\left(6.0 \times 10^{6}\right.$ spores) were pre-incubated at $20^{\circ} \mathrm{C}$ for $30 \mathrm{~min}$ in $0.8 \mathrm{ml}$ of assay medium containing the substances released from $1.2 \times 10^{7}$ spores on a shaker at 100 strokes $/ \mathrm{min}$. Then varied amounts of SA factor and $10 \mu \mathrm{mol}$ of $\mathrm{CaCl}_{2}$ in $0.2 \mathrm{ml}$ of volume were added to the mixture, which was incubated for another $30 \mathrm{~min}$ to assay for agglutination.

\begin{tabular}{|c|c|c|c|}
\hline \multirow{2}{*}{$\begin{array}{l}\text { Concentration of } \\
\text { SA factor } \\
\text { Galacturonic acid } \\
\text { equivalent } / \mathrm{ml}\end{array}$} & \multicolumn{3}{|c|}{ Relative agglutination } \\
\hline & $\begin{array}{l}\text { Germinated } \\
\text { spores } \\
\text { pre-incubated } \\
\text { with water }\end{array}$ & $\begin{array}{l}\text { Sonicated } \\
\text { spores } \\
\text { pre-incubated } \\
\text { with water }\end{array}$ & $\begin{array}{c}\text { Sonicated spores } \\
\text { pre-incubated with } \\
\text { sonication-released } \\
\text { substances }\end{array}$ \\
\hline \multicolumn{4}{|l|}{ ng } \\
\hline 0 & - & - & - \\
\hline 25 & - & +1 & - \\
\hline 50 & - & +1 & - \\
\hline 75 & - & +2 & - \\
\hline 100 & - & +2 & - \\
\hline 125 & - & +3 & - \\
\hline
\end{tabular}

TABle II. EfFEcts of Trypsin-treatment of SAI Substances on ACTIVITY

The SAI substances were treated by trypsin as described under MATERIALS AND METHODS, and assayed for the activity after being diluted serially with water. In control (1), SAI substances were treated in the mixture which contained no trypsin but contained trypsin inhibitor. In control (2), the mixture which contained no SAI substances but contained both trypsin and trypsin inhibitor was added to assay mixture.

\begin{tabular}{cccc}
\hline $\begin{array}{c}\text { Dilution of } \\
\text { SAI substances } \\
\text { solution }\end{array}$ & Treated & Control (1) & Control (2) \\
\cline { 2 - 4 } & & & \\
Fold & - & - & + \\
1 & \pm & - & + \\
2 & + & - & + \\
4 & + & - & + \\
8 & + & - & + \\
16 & + & \pm & + \\
32 & + & + & + \\
64 & & & + \\
\hline
\end{tabular}

completely by heat treatment at $100^{\circ} \mathrm{C}$ for 3 min (data not shown). Trypsin inactivated the SAI substances (Table II). These results suggest the proteinous nature of the SAI substances. When SAI substance solution was adjusted to various $\mathrm{pHs}$ and incubated at $4^{\circ} \mathrm{C}$ for $16 \mathrm{hr}$, the largest activity $(80 \%)$ was recovered in the precipitate at $\mathrm{pH}$ 4.0. The results suggest that SAI substances are acidic proteins with a pI of about 4 .

\section{Effects of $\mathrm{pH}$ and $\mathrm{Ca}^{2+}$ on re-binding of $\mathrm{SAI}$ substances onto sonicated spores of sweet potato strain}

As described in the preceding section, the sonicated spores became insensitive to SA factor when they were pre-incubated with the substances released by sonication. It was most plausible that acquisition of insensitiveness was caused by re-binding of SAI substances onto the surface of the spores. Therefore, we studied the effects of $\mathrm{pH}$ and $\mathrm{Ca}^{2+}$ on rebinding of SAI substances onto the sonicated spores (Table III). The sonicated spores were pre-incubated in mixture of various $\mathrm{pHs}$ containing SAI substances with or without $\mathrm{CaCl}_{2}$ $(10 \mathrm{~mm})$. Then spores were washed once with water by centrifugation and assayed for agglutination. At pH 5.5 and 7.5, the sonicated spores pre-incubated in the mixture containing both SAI substances and $\mathrm{Ca}^{2+}$ showed the same reactivity to SA factor as those in controls. On the other hand, spore agglutination 
TABle III. EfFects of pH AND $\mathrm{Ca}^{2+}$ on Re-Binding of SAI Substances onto Sonicated Spores of Sweet Potato Strain

The germinated spores $\left(6 \times 10^{6}\right.$ spores $)$ of the sweet potato strain after sonication-treatment were preincubated in $1.0 \mathrm{ml}$ of $20 \mathrm{~mm}$ MES-NaOH buffer, $\mathrm{pH} 5.5,6.5$ or 7.5 containing $60 \mu \mathrm{g}$ protein of SAI substances with or without $10 \mu \mathrm{mol}$ of $\mathrm{CaCl}_{2}$ at $25^{\circ} \mathrm{C}$ on a shaker, 100 strokes/min. In controls, water was added to the mixture instead of SAI substances and $\mathrm{CaCl}_{2}$. After pre-incubation for $1 \mathrm{hr}$, the spores were washed once with $1 \mathrm{ml}$ of water by centrifugation and assayed for agglutination using the varied concentrations of SA factor by the assay method described under Materials AND METHODS.

\begin{tabular}{|c|c|c|c|c|c|c|c|c|c|}
\hline \multirow{3}{*}{$\begin{array}{l}\text { Concentration } \\
\text { of SA factor } \\
\text { Galaturonic } \\
\text { acid } \\
\text { equivalent } / \mathrm{ml}\end{array}$} & \multicolumn{9}{|c|}{ Relative agglutination } \\
\hline & \multicolumn{3}{|c|}{$\mathrm{pH} 5.5$} & \multicolumn{3}{|c|}{$\mathrm{pH} 6.5$} & \multicolumn{3}{|c|}{$\mathrm{pH} 7.5$} \\
\hline & None & $\begin{array}{c}\text { SAI } \\
\text { substances }\end{array}$ & $\begin{array}{c}\text { SAI } \\
\text { substances } \\
+\mathrm{Ca}^{2+}\end{array}$ & None & $\begin{array}{c}\text { SAI } \\
\text { substances }\end{array}$ & $\begin{array}{c}\text { SAI } \\
\text { substances } \\
+\mathrm{Ca}^{2+}\end{array}$ & None & $\begin{array}{c}\text { SAI } \\
\text { substances }\end{array}$ & $\begin{array}{c}\text { SAI } \\
\text { substances } \\
+\mathrm{Ca}^{2+}\end{array}$ \\
\hline \multicolumn{10}{|l|}{$\mathrm{ng}$} \\
\hline 0 & - & - & - & - & - & - & - & - & - \\
\hline 25 & +1 & +1 & +1 & +1 & +1 & - & - & - & - \\
\hline 50 & +1 & +2 & +2 & +2 & +1 & - & - & - & - \\
\hline 75 & +1 & +3 & +3 & +2 & +1 & - & +1 & +1 & +1 \\
\hline 100 & +2 & +3 & +3 & +3 & +2 & - & +1 & +1 & +1 \\
\hline 125 & +3 & +3 & +3 & +3 & +2 & +1 & +2 & +2 & +2 \\
\hline
\end{tabular}

was specifically inhibited by SAI substances at pH 6.5 in the presence of $\mathrm{Ca}^{2+}$. The results suggested that SAI substances re-bound efficiently onto the surface of the sonicated spores at $\mathrm{pH} 6.5$ in the presence of $\mathrm{Ca}^{2+}$ $(10 \mathrm{~mm})$. Based on the result, the activity of SAI substances was assayed at $\mathrm{pH} 6.5$ in the presence of $\mathrm{Ca}^{2+}(10 \mathrm{mM})$ in this paper.

\section{Effects of SAI substances on agglutination of} germinated spores of various strains of $C$. fimbriata

The germinated (not sonicated) spores of various strains were pre-treated with a fixed concentration, $36 \mu \mathrm{g}$ of protein equivalent $/ \mathrm{ml}$, of SAI substances. After washing, the treated spores were assayed for agglutinability in mixtures containing varied amounts of SA factor (Table IV). SAI substances inhibited the agglutination of germinated spores of all strains, but differential agglutination was still observed among strains. The result suggested that SAI substances diminished the sensitivity of germinated spores of all strains by a similar degree but did not cancel their inherent differential agglutinability.

\section{Effects of SAI substances on growth of various} strains of $C$. fimbriata in liquid media

The ungerminated spores of various strains were cultured in mixtures with or without SAI substances for $18 \mathrm{hr}$ at $25^{\circ} \mathrm{C}$. SAI substances showed different effects on growth among strains (Fig. 1A). The growth of sweet potato, coffee, cacao, and taro strains were stimulated, whereas that of prune, oak, and almond strains was inhibited. On the other hand, SAI substances which had been boiled for $5 \mathrm{~min}$ showed little effect on growth (Fig. 1B).

\section{DISCUSSION}

In the present study, we isolated the SAI substances from the germinated spores of the sweet potato strain which inhibited sporeagglutination by SA factor. SAI substances were assumed to be proteins because of their inactivation by heat and trypsin treatments. SAI substances from spores of the sweet potato strain seemed to re-bind onto the surface of germinated spores of not only the sweet potato strain but also the other six strains and inhibit their agglutination by SA factor. 
Table IV. Effects of SAi Substances on Agglutination of Germinated Spores of Various Strains of $C$. fimbriata

The germinated (not sonicated) spores $\left(6 \times 10^{6}\right.$ spores) of various strains were treated by incubating in $1.0 \mathrm{ml}$ mixture containing $36 \mu \mathrm{g}$ protein of SAI substances, $10 \mu \mathrm{mol}$ of MES-NaOH buffer $\mathrm{pH} 6.5$ and $5 \mu \mathrm{mol}$ of $\mathrm{CaCl}_{2}$ at $25^{\circ} \mathrm{C}$ on a shaker, 100 strokes/min. After incubation for $1 \mathrm{hr}$, the spores were washed 3 times with $1.0 \mathrm{ml}$ of $10 \mathrm{~mm}$ MES-NaOH buffer, $\mathrm{pH} 6.5$ with $5 \mu \mathrm{mol}$ of $\mathrm{CaCl}_{2}$ by centrifugation and then assayed for agglutination using the varied concentration of SA factor by the method described under MATERIALS AND METHODS. Agglutination of untreated spores was also assayed as controls.

\begin{tabular}{|c|c|c|c|c|c|c|c|c|c|c|c|c|c|c|}
\hline \multirow{3}{*}{$\begin{array}{l}\text { Concentration } \\
\text { of SA factor } \\
\text { Galacturonic } \\
\text { acid } \\
\text { equivalent } / \mathrm{ml}\end{array}$} & \multicolumn{14}{|c|}{ Relative agglutination } \\
\hline & \multicolumn{2}{|c|}{$\begin{array}{l}\text { Sweet potato } \\
\text { strain }\end{array}$} & \multicolumn{2}{|c|}{ Coffee strain } & \multicolumn{2}{|c|}{ Prune strain } & \multicolumn{2}{|c|}{ Cacao strain } & \multicolumn{2}{|c|}{ Oak strain } & \multicolumn{2}{|c|}{ Taro strain } & \multicolumn{2}{|c|}{ Almond strain } \\
\hline & $\begin{array}{l}\text { Non- } \\
\text { treated }\end{array}$ & Treated & $\begin{array}{l}\text { Non- } \\
\text { treated }\end{array}$ & Treated & $\begin{array}{l}\text { Non- } \\
\text { treated }\end{array}$ & Treated & $\begin{array}{l}\text { Non- } \\
\text { treated }\end{array}$ & Treated & $\begin{array}{l}\text { Non- } \\
\text { treated }\end{array}$ & Treated & $\begin{array}{l}\text { Non- } \\
\text { treated }\end{array}$ & Treated & $\begin{array}{l}\text { Non- } \\
\text { treated }\end{array}$ & Treated \\
\hline ng & & & & & & & & & & & & & & \\
\hline 0 & - & - & - & - & - & - & - & - & - & - & - & - & - & - \\
\hline 30 & - & - & - & - & - & - & - & - & - & - & - & - & - & - \\
\hline 60 & - & - & - & - & - & - & +1 & - & +1 & - & - & - & - & - \\
\hline 90 & - & $\therefore$ & +1 & - & +1 & - & +2 & - & +2 & - & +1 & - & - & - \\
\hline 120 & - & - & +2 & - & +2 & +1 & +3 & +1 & +3 & +1 & +2 & - & - & - \\
\hline 150 & - & - & +2 & +1 & +2 & +2 & +3 & +2 & +3 & +2 & +2 & +1 & +1 & - \\
\hline 180 & +1 & - & +3 & +2 & +3 & +2 & +3 & +2 & +3 & +2 & +3 & +2 & +2 & - \\
\hline
\end{tabular}



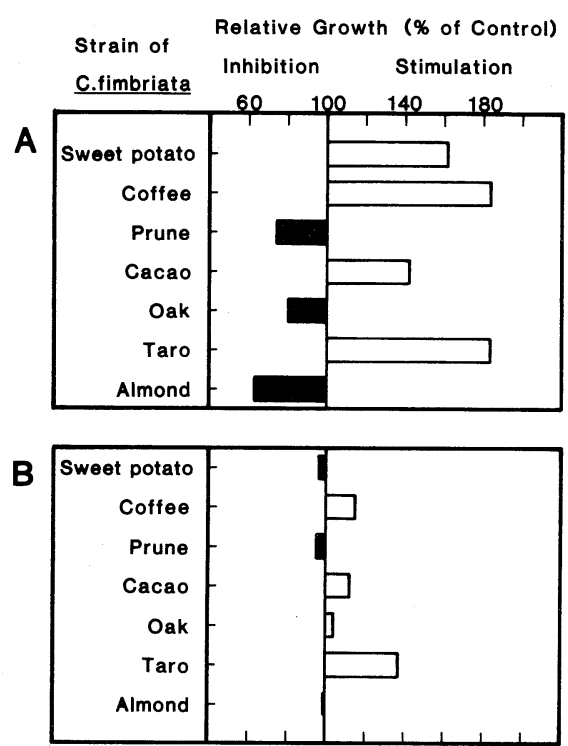

FIG. 1. Effects of Intact SAI Substances (A) and HeatTreated SAI Substances (B) on Growth of Various Strains of C. fimbriata.

Experimental conditions are described in text. In Fig. 1A, intact SAI substances were used, while SAI substances boiled for $5 \mathrm{~min}$ were used in Fig. 1B. The results are the average of three separate experiments.

At present, we speculate that the following may be the molecular basis for the differential sensitivity to SA factor which the spores of various strains of $C$. fimbriata show after germination, as mentioned in the introduction. A similar number of supposed receptors for SA factor are exposed on the ungerminated spores of various strains, because they showed similar sensitivity to SA factor. When spores germinate, varied amount of SAI substances appear and partially cover the receptors on the surface of spores of various strains. This was suggested when germinated spores of various strains showed differential sensitivity to SA factor and the differential sensitivity was abolished by the release of SAI substances from the spore surface. ${ }^{13)}$ The largest amount of SAI substances appear on the spore surface of the sweet potato and almond strains, resulting in a decrease of sensitivity to SA factor, while there are only limited amounts of them on surface of other strains, resulting in retention of sensitivity to SA factor.
SAI substances also affected the growth of C. fimbriata in liquid media; the substances stimulated the growth of sweet potato, coffee, cacao, and taro strains but inhibit that of prune, oak, and almond strains. The stimulating and inhibitory activities of SAI substances on the growth of $C$. fimbriata were inactivated by heat treatment as was their agglutinationinhibitory activity. However, the result does not rule out the possibility that different entities affect the agglutination and growth of spores. It is likely that SAI substances affect the growth through binding onto surface of germ tubes or hyphae of $C$. fimbriata.

Previously, ${ }^{12)}$ we showed that sporeagglutinating factor (SA factor) from sweet potato roots inhibit the growth of $C$. fimbriata. It is reasonable to speculate that SA factor, which is a high molecular weight carbohydrate, also inhibited growth through binding onto the surface of fungi. Thus, the growth of C. fimbriata seems to be deeply affected by the substances which interact with surface of the fungi. Some components of host plants, such as spore-agglutinating factor (SA factor), could interact with some components such as spore-agglutination inhibitory substances (SAI substances) on the surface of germ tubes or hyphae and could differently affect the growth of various strains on the host tissues. Such interactions between fungi and components of host plants might determine host-parasite specificity.

\section{REFERENCES}

1) A. J. Anderson and C. Jasalavich, Physiol. Plant Pathol., 15, 149 (1979).

2) B. B. Bohlool and E. Schmidt, Science, 185, 259 (1974).

3) F. B. Dazzo, W. E. Yanke and W. J. Brill, Biochim. Biophys. Acta, 539, 276 (1978).

4) F. B. Dazzo and W. J. Brill, J. Bacteriol., 137, 1362 (1979).

5) F. B. Dazzo, G. L. Truchet and J. W. Kijne, Physiol. Plant, 56, 143 (1982).

6) P-Y. Huang, J. Huang and R. N. Goodman, Physiol. Plant Pathol., 6, 283 (1975).

7) R. Romeiro, A. Karr and R. Goodman, Plant Physiol., 68, 772 (1981). 
8) L. Sequeira and T. L. Graham, Physiol. Plant Pathol., 11, 43 (1977).

9) A. J. Slusarenko and R. K. S. Wood, Physiol. Plant Pathol., 18, 187 (1981).

10) M. Kojima and I. Uritani, Plant \& Cell Physiol., 15, 733 (1974).

11) M. Kojima and I. Uritani, Plant Physiol., 62, 751 (1978).

12) M. Kojima, K. Kawakita and I. Uritani, Plant Physiol., 69, 474 (1982).
13) K. Kawakita and M. Kojima, Plant \& Cell Physiol., 24, 41 (1983).

14) M. Kojima and I. Uritani, Plant \& Cell Physiol., 19, 91 (1978).

15) T. Bitter and H. M. Muir, Anal. Biochem., 4, 330 (1962).

16) N. Blumenkrantz and G. Asboe-Hansen, Anal. Biochem., 54, 484 (1973).

17) O. H. Lowry, N. J. Rosebrough, A. L. Farr and R. J. Randall, J. Biol. Chem., 193, 265 (1951). 